\title{
Vivir en estado de búsqueda. Las Antígonas modernas del desierto y el Río de la Plata
}

\section{To Live in a State of Search. The Modern Antigones of the Desert and Rio de la Plata}

\author{
Cynthia Shuffer \\ Universidad de Santiago de Chile \\ cynthia.shuffer@usach.cl
}

\section{Resumen}

El presente texto busca poner en evidencia las relaciones intertextuales que existen entre el mito de Antígona y otros relatos - audiovisuales, fotográficos y teatrales-con el fin de ir desentrañando la potencia vital de sus protagonistas. El legado del arquetipo de Antígona se hace presente en los hipertextos como una fuerza desobediente a los mandatos oficiales, una figura femenina que se resiste a la injusticia y al orden patriarcal impuesto por las leyes de la ciudad de Tebas. El documental Nostalgia de la luz, del chileno Patricio Guzmán, la obra de teatro uruguaya Antígona Oriental, de Volker Lösch y Marianella Morena y el Siluetazo realizado por las Madres de Plaza de Mayo en compañía de tres artistas visuales serán las obras que nos permitirán aproximarnos a la figura de Antígona desde los testimonios de las mujeres que perdieron a sus hermanos, padres e hijos - descendientes de Polinices- en el marco de las dictaduras de los años setenta en el Cono Sur.

Palabras clave: Antígona, mito, dictadura, desaparición forzada, duelo.

\section{Abstract}

The present text seeks to highlight the intertextual connections that exist between the myth of Antigone and other relations-audiovisual, photographic and theatrical—in order to unravel the vital power of its protagonists. The legacy of the Antigone archetype is present in hypertexts as a disobedient force towards official mandates, a female figure who resists injustice and the patriarchal order imposed by the laws of the city of Thebes. The documentary Nostalgia de la luz by the Chilean Patricio Guzmán, the Uruguayan theater play Antígona Oriental by Volker Lösch and Marianella Morena and the Siluetazo (silhouette drawings on the ground) made by the Mothers of Plaza de Mayo in the company of three visual artists will be the works that will allow us to get closer to the Antigone figure from the testimonies of the women who lost their brothers, parents and children-descendants of Polinices-in the framework of the dictatorships of the seventies in the Southern Cone.

Keywords: Antigone, myth, dictatorship, enforced disappearance, mourning. 


\section{Presentación del corpus}

El presente texto busca poner en evidencia las relaciones intertextuales que existen entre el mito de Antígona y otros relatos - audiovisuales, fotográficos y teatrales-con el fin de ir desentrañando la potencia vital de las mujeres que protagonizan estas obras. El legado del arquetipo de Antígona se hace presente en los hipertextos como una fuerza resistente al orden patriarcal y los mandatos oficiales, una figura de lucha conmovida por la materialización de una política injusta. De acuerdo con esto proponemos, al menos para este análisis, tres estructuras simbólicas significativas o mitemas: en primer lugar, el enfrentamiento de dos fuerzas antagónicas dispares, representadas por la ley impuesta por Caronte frente a la ley divina —entendida culturalmente como ley de parentesco- interpretada por Antígona y su deseo de rendirle honores fúnebres a su hermano Polinices; en segundo lugar, la figura del castigo ejemplificador para quienes traicionan las leyes de la ciudad y el Estado, negándoles así la posibilidad de un funeral apropiado, dejando a merced el cuerpo ingrato y condenando a muerte a quien pretenda violar esta orden; $y$, por último, la desobediencia como acto de protesta ante una ley injusta. Estas estructuras, si bien responden al contexto particular de la obra mítica original, poseen en sí mismas un grado importante de actualidad que desborda el relato mítico, abriéndose a variantes contextuales, históricas y simbólicas de gran rendimiento y dinamismo en el presente y en las obras que trabajaremos más adelante.

La Antígona de Sófocles es un poderoso instrumento de reflexión política, pues presenta el retrato de una mujer que, motivada por la libertad y la fidelidad a su familia, alza su voz ante los designios terrenales, representados por las leyes proclamadas por su tío Creonte, para finalmente ejercer su derecho en un acto público, pese a saberse en peligro. Antígona, afectada por la ausencia de su padre y de sus hermanos, clama justicia por el cuerpo insepulto de Polinices, invocando a los mandatos divinos — cosmogónicos- que reservan un lugar a los vivos y a los muertos. Así, víctima de su destino, es condenada a muerte por buscar la restitución, es decir, honrar a los muertos mediante ritos funerarios, frente a una transgresión — hybris - cometida por parte de su familia.

El conflicto de poder presente en el relato mítico pone en juego una serie de disposiciones propias de las tradiciones ancestrales, las formas de gobierno del Estado democrático ateniense, el que aparece representado en el drama de Sófocles como una autoridad arbitraria y opresora, y el ejercicio de un derecho individual. Podemos visualizar, en el diálogo entre estas, el enfrentamiento de una conciencia individual -obediente a los designios divinos y políticos - contra el bien común, interpretado por los buenos intereses de Creonte para la ciudad y sus habitantes. El poder omnipotente del Estado instala una ética de la responsabilidad, encargada de administrar sanciones en contra de quienes se rebelan ante sus mandatos y a favor de aquellos que enaltecen los valores de la ciudad. Creonte señala en su conversación con Corifeo: "y a un hombre no tendría por amigo si fuera de esta tierra enemigo, pues pienso que la Patria será la que nos salve y que, con buen gobierno, nos haremos 
amigos" (Sófocles 24). Esta medida común dicta una sentencia, disposición de una democracia utilitaria y parcial, por sobre toda experiencia particular o divina en la construcción del argumento mítico.

La ley de Creonte impide la entrada de Polinices al mundo de los muertos desde el mundo de los vivos, relegándolo al umbral entre estos dos universos, descrito por Eliade como el hito o frontera donde se distinguen y oponen, un espacio de tránsito entre lo profano y lo sagrado (Lo sagrado 7). En ese sentido, el sepulcro sería el lugar donde se "guardan los fragmentos de una unidad que no se pude reunir y a cuya dispersión nos resistimos" (Marín 313), otorgándole un sentido específico a la muerte, abriendo el camino hacia el Hades e impidiendo que el alma vague por una tierra sin retorno como espectros anómalos que amenazan el orden divino. Por su parte, el cuerpo expuesto, repugnante a la vista, dice Creonte, se identifica con los sin nombre, con quienes vivieron sin gloria y murieron bajo esas leyes. Fue así como Antígona, arrebatada por el amor profundo que siente por su hermano y movida por una voluntad inquebrantable, desafía las leyes del monarca y decide enterrar a Polinices. Ella sabe que está destinada a morir una vez cumplido su propósito, sin embargo, prefiere este padecer antes que traicionarse a sí misma y a su propio linaje.

Los textos propuestos para el siguiente análisis son protagonizados por mujeres que realizaron la misma lucha de Antígona frente al poder, transgrediendo los límites impuestos con el objetivo de transformar la historia. Dichas mujeres fueron protagonistas de un escenario conflictivo y vivieron las dictaduras del Cono Sur desde una perspectiva particular, es decir, desde la resistencia y la militancia hasta la pérdida y búsqueda de sus familiares. El carácter documental de las obras seleccionadas guarda una conexión directa con estas vivencias, pues rescata y retrata sus testimonios con el fin de crear un argumento estético de denuncia. Las mujeres que aparecen en el documental Nostalgia de la luz _ particularmente las entrevistas de Violeta Berrios y Vicky Saavedra, las ex presas políticas que protagonizan el coro de la obra de teatro uruguaya Antígona Oriental - y las fotografías de las acciones de las Madres de Plaza de Mayo son parte del repertorio de historias atravesadas por el mito de Antígona y que presentan en su estructura experiencias propias del mito, que perviven y se manifiestan constantemente. Estas obras acompañan el trayecto doloroso de la heroína a partir de tres imaginarios distintos: el impulso emotivo, el testimonio militante y el registro fotográfico y artístico de sus luchas.

El documental Nostalgia de la luz (2010) de Patricio Guzmán es un filme que presenta mediante imágenes y entrevistas el trabajo y búsqueda que realizan algunas personas en el desierto de Atacama. Por un lado, describe las reflexiones y motivaciones de un grupo de astrónomos que buscan responder las grandes interrogantes de la ciencia a partir de la observación acuciosa del cielo chileno. A esto, se suma la labor realizada por arqueólogos que pretenden encontrar en los cuerpos ancestrales respuestas sobre el presente. Por su parte, un grupo de mujeres remueve las piedras del desierto en busca de las huellas y restos de sus familiares con el fin de conocer 
FIGURA 1

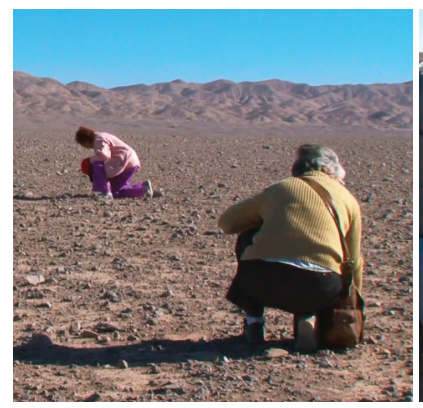

FIGURA 2

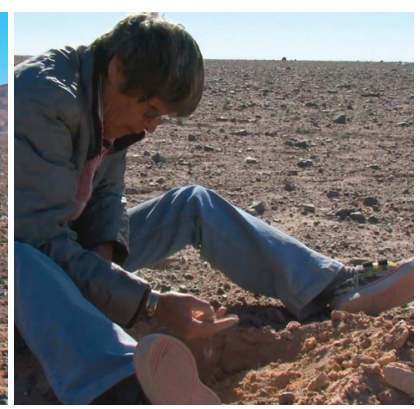

FIGURA 3

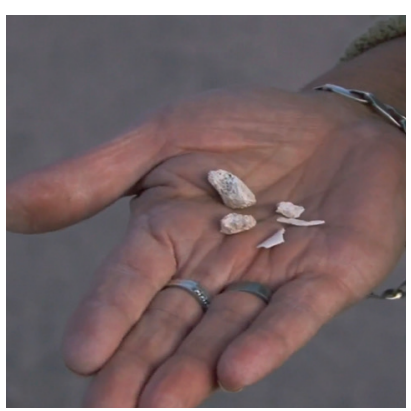

Vicky Saavedra y Violeta Berrios buscan restos de sus familiares en el desierto. Fotogramas del documental Nostalgia de la luz, Patricio Guzmán, 2010.

cuál fue su destino y poder despedirse de ellos. Los lenguajes científicos que el documental utiliza como herramienta interpretativa del pasado se van entretejiendo con la historia reciente de la dictadura en Chile, particularmente con los testimonios de estas personas que perdieron a sus hermanos en la Caravana de la Muerte, representando varios modos de estar en el presente. En ese sentido, el cine documental como artificio "posibilita metáforas y abre caminos para un viaje por el tiempo, capaz de intervenir los anclajes materiales de la memoria" (Vitullo 179) en las experiencias de quienes conviven en el desierto.

La obra de teatro uruguaya Antígona Oriental (2012), escrita por Marianella Morena y dirigida por Volker Lösch, se crea a partir de un trabajo de investigación y reescritura del mito de Antígona, que incluye testimonios de ex presas políticas, hijas y exiliadas de la dictadura militar de 1973. El coro femenino, integrado en tu totalidad por un grupo representativo de mujeres que sufrieron abusos durante ese periodo, denuncia las situaciones de injusticia social llevadas a cabo por los militares mientras que Antígona, Ismena y los Creontes dialogan entre sí. Los recuerdos de la cárcel, allanamientos, persecuciones, muertes y desapariciones son parte de las historias que presentan estas mujeres, movidas fuertemente por la militancia y el amor por sus compañeros y compañeras. La obra, apostada en el presente posdictatorial, busca remover los olvidos producidos por el poder mediante la Ley de Caducidad de la Pretensión Punitiva del Estado (1986), instalando una cadena de acciones simbólicas y voces que cuestionan la supuesta superación del conflicto. El despliegue estético de este documento ficcionalizado impacta al espectador a través de un texto dramático constante y directo que busca movilizar la conciencia hacia un lugar de enunciación propio. 
FIGURA 4

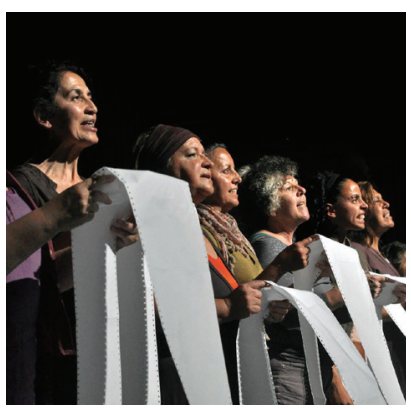

Registro de la obra Antígona Oriental, Gustavo Castagnello, 2012.
FIGURA 5

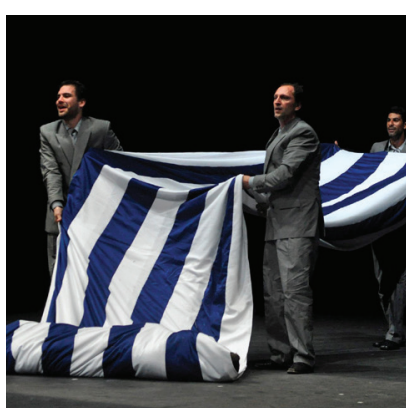

Registro de la obra Antígona Oriental, Martha Passeggi, 2012.
FIGURA 6

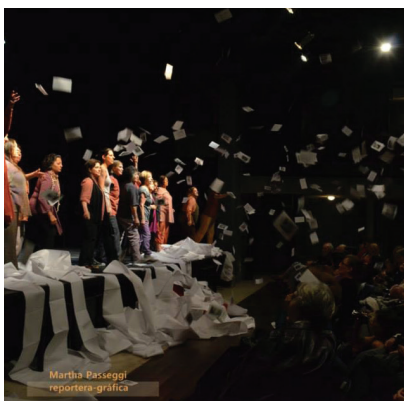

El 21 de septiembre de 1983, pocos meses antes del final de la dictadura, las Madres de Plaza de Mayo convocan a la tercera Marcha de la Resistencia, organizada por una asamblea en la que participaron tres artistas visuales - Rodolfo Aguerreberry, Julio Flores y Guillermo Kexel- quienes plantearon crear decenas de miles de siluetas a escala humana pintadas sobre papel en representación de los detenidos desaparecidos (Longoni y Bruzzone 7). El llamado Siluetazo "era, en su origen, una propuesta artística; pero fue su desbordamiento hacia el campo social y su socialización anónima en el seno de los movimientos por los derechos humanos en Argentina lo que finalmente le dio entidad" (Expósito 3). Los recorridos y acciones realizadas por las Madres, particularmente el Siluetazo y las marchas circulares en la Plaza de Mayo, son parte de las prácticas artísticas y políticas, dispositivos específicos en la lucha por los derechos de quienes fueron vulnerados.

La ciudad de Tebas, transmutada como territorio chileno, uruguayo y argentino, es el escenario para estas historias. Las mujeres que los habitan resucitan constantemente la figura de Antígona porque viven o reviven la catástrofe autoritaria y genocida de las dictaduras de los años setenta, en la que sus hermanos, padres e hijos - descendientes de Polinices - fueron asesinados o desaparecidos. La realización del sagrado rito fúnebre, instancia buscada y jamás diferida, se convierte en una lucha sistemática, acompañada de gestos de amor y solidaridad propios en la historia de la heroína mítica. De este modo, las estructuras simbólicas señaladas anteriormente toman contacto con las imágenes y sentidos de las obras contemporáneas, descifrando a través de estas unidades de análisis el lugar de la violencia ejercida en el enfrentamiento de dos fuerzas significativamente dispares, entre un Estado que operativiza un castigo ejemplar para doblegar al cuerpo social mermado por las duras leyes dictatoriales, 
FIGURA 7

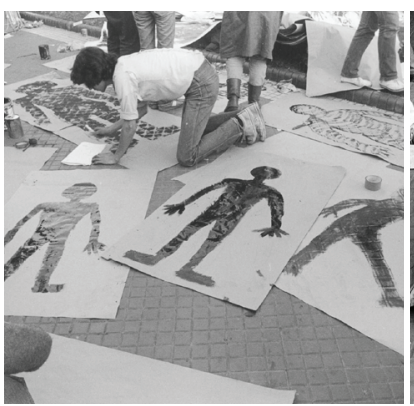

FIGURA 8

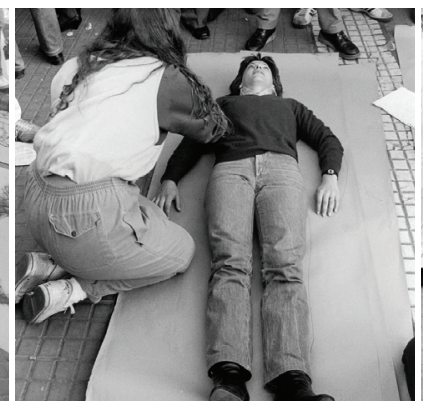

FIGURA 9

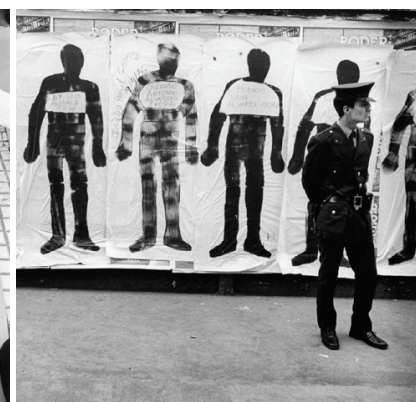

Registro acción Siluetazo, Eduardo Gil, 1983.

mientras que un grupo de mujeres sobrevivientes van articulando por fuera una serie de actos de rebeldía como forma de desobedecer y quebrar el espiral de violencia e injusticia al que fueron expuestas.

\section{El enfrentamiento de dos fuerzas desiguales}

El mito, entendido desde la perspectiva de Eliade, "cuenta una historia sagrada o relata un acontecimiento que ha tenido lugar en el tiempo primordial" (Eliade, Mito y realidad 7) y que puede ser revisitado desde una óptica contemporánea. La vida ejemplar descrita en el relato mítico nos proporciona un modelo o guía para comprender las actividades humanas, otorgándoles un valor y una significación a la existencia. En la obra mítica, destacamos dos experiencias particulares de quienes se enfrentaron contra la fuerza ejercida por Creonte - Estado autoritario-, encarnando un tipo de fortaleza individual inexpugnable: nos referimos a Antígona y Polinices. La oposición entre tirano y oprimido, entre autoridad abusiva e insubordinación presentes en la tragedia griega nos permiten reflexionar sobre los límites y desafíos de la Polis. En ese sentido, los mitos "no tienen solo un componente político potencial o concretamente revulsivo sino también un esquema de moralización” (Lariguet 301), pues son los hombres y mujeres nobles quienes experimentan la caída y el dolor ocasionado por esta. Esto se relaciona con la utilización de la palabra víctima en vez de protagonista de la historia, desplazando la militancia a un segundo plano, enalteciendo la idea de mártir.

La ley que prohíbe y ordena las actividades de la ciudad de Tebas, en cierta medida, es similar a la ley represiva de las dictaduras de estos países. La relación intertextual entre las obras y el relato mítico proporciona nuevas interpretaciones de las ciudades y sus contextos. En ese sentido, "la imagen nueva injertada sobre una antigua imagen" (Bachelard 31), permite visualizar, desde otra perspectiva, la transgresión de Creonte. 
La figura arquetípica del monarca somete a los ciudadanos a sus mandatos, enalteciendo los valores patrios por sobre todas las otras normas. Los habitantes parecen estar dispuestos a obedecer, a pesar de que algunos manifiestan su descontento. Sin embargo, sobrepasar los límites divinos - familiares, morales, religiosos- supone un costo, un castigo, reflejado en el empobrecimiento de la vida. Los dictadores, por su parte, ejercen este mismo deber mediante lógicas de dominación y aniquilación de las identidades políticas resistentes. Esto queda de manifiesto cuando uno de los Creontes de Antígona Oriental (2012) señala "No existe mayor mal que la anarquía que destruye las ciudades y devasta los hogares, en cambio la obediencia, salva la vida de los que siguen el rumbo correcto, por lo tanto hay que apoyar las órdenes de los que mandan". Esta supuesta anarquía, representada por los gestos de desobediencia de los hijos de Edipo, también se encuentra encarnada en los protagonistas de las obras propuestas para este análisis.

El gesto funerario de Antígona, desde una perspectiva política, establece un acto "oximorónico de una ley en contra de otra ley: la reparación criminal del agravio imita con sutileza la subversión propia de los regímenes autoritarios simbolizados por Creonte" (Duroux 78), en ese sentido, las Antígonas modernas buscan encarar al poder represor, denunciando las desapariciones de sus familiares en las dictaduras de los años setenta. En el documental Nostalgia de la luz (2010) una exiliada política señala que "las mujeres que buscan a sus muertos exigen respuestas de los que los hicieron desaparecer", sin embargo, la disputa de dos fuerzas tan desiguales no permite realizar sus deseos. El autoritarismo masculino desplaza la voz femenina bajo disposiciones de incapacidad política, tal como Creonte menciona en el texto mítico "si debemos caer será siempre mejor caer por viril mano: no se dirá que fuimos, como mujeres, débiles" (Sófocles 53). Siguiendo esta idea, la valiente presencia de las Madres en la Plaza de Mayo "tuvo su origen en la negativa de los militares a recibirlas; las rondas alrededor de la pirámide surgieron como respuesta a las órdenes de la policía de que circulen y los pañuelos blancos fueron adoptados como solución al dilema de cómo identificarse entre sí en la multitud" (Longoni y Bruzzone 413). Estas mujeres marcharon durante siete años en círculo, esperando que las autoridades comprendieran el sentido de su insistencia.

Si bien la muerte de los hermanos de Antígona por la continuidad del reino no se encuentra explicitada en el texto de Sófocles, es posible identificar la traición y venganza que motiva esta escena. Eteocles, una vez cumplido su mandato, no quiere dejar el trono, contraviniendo la norma acordada con su hermano, abriéndole paso a la maldición que cae sobre ellos desde los tiempos de su padre. Polinices decide abandonar su ciudad, convertirse en un caudillo y volver para conquistar el trono por la fuerza. Si bien no se repara en el gesto traicionero de Eteocles, una vez muertos, es Polinices quien recibe el castigo desmedido de Creonte. La pulsión justiciera y el deseo de poder fracasan ante lo que ya estaba predicho: la muerte como destino tuvo como consecuencia un cuerpo insepulto sin posibilidad de duelo. 
Ahora bien, los descendientes de Polinices, resistentes al periodo dictatorial, tuvieron la misma condena, fueron torturados, asesinados y desaparecidos por luchar por lo que consideraban justo. El coro de mujeres de la obra Antígona Oriental (2012) se encarga insistentemente de recordar aquellas vejaciones provocadas en los cuerpos de sus compañeras y compañeros de militancia: "me ponen contra la pared y me dan piñazos. Me hacen torniquetes en los pezones con los palillos de la ropa. Me lastiman tanto que mi ropa queda toda ensangrentada y así se la mandan a mi familia. Lo primero que reciben como noticia mía fue mi ropa ensangrentada y con materia fecal podrida. Mi familia piensa que me mataron". La función social que cumplió la represión se encargó de aniquilar con una fuerza desmedida los rastros de quienes se levantaban contra lo que se consideraba bueno y posible para esos tiempos.

El castigo que cae sobre Creonte debido a la transgresión cometida, arrebatándole a su hijo y a su esposa, conlleva un tipo de arrepentimiento por parte del monarca. La mirada estrecha que provoca la hybris solo se despeja cuando se ve solo y sin apoyo de su pueblo. Algo similar ocurre en Antígona Oriental (2012) cuando los Creontes se dirigen a los ciudadanos presentes: "Hoy el estado uruguayo pide formal y públicamente disculpas por las atrocidades cometidas en la dictadura, en esa larga noche de 1973 a 1985 donde todos los uruguayos sufrieron el terrorismo de estado, en esa larga noche donde los uruguayos fueron excluidos de todos sus derechos, en esa larga noche donde vivir y ser feliz fue la más grande de las utopías". Sin embargo, el perdón simbólico no encuentra su referente en la realidad, pues los crímenes cometidos en dictadura aún continúan impunes, sin solución y sin justicia. La herida abierta y el "Nunca más" promulgado por las Madres de Plaza de Mayo se encuentran suspendidos por las políticas refrendadas en democracia - leyes de punto final y archivos ocultos - las que, salvo en el caso argentino, se mantuvieron a favor de las Juntas Militares y en contra de los habitantes de las Tebas latinoamericanas.

\section{El cuerpo insepulto como castigo ejemplificador}

Luego de la batalla por la ciudad, Creonte señala que “jamás los malvados recibirán honores en lugar de los justos” (Sófocles 24), refiriéndose al episodio de insurrección perpetrado por el hermano de Antígona. La prohibición de sepultar el cuerpo relega al individuo a un estatus de paria, privándolo de sus derechos civiles y divinos. Para los griegos estar condenados a vagar por el Styx significa un sufrimiento tanto para los vivos como para los muertos (Déotte en Richard 94), pues el cuerpo en cuestión padecería los peores tormentos durante cien años. El daño imaginado por los familiares sobrevivientes resulta insoportable; es por esto que se realizan todo tipo de ritos para conducir sus almas directamente al Hades y renovar su ciclo vital. Pero dejar un cuerpo insepulto también supone un castigo ejemplificador para quienes miran con temor los restos de los desobedientes. Instalar la muerte como un tipo de sanción es el objetivo de 
la mente criminal de Creonte y de los dictadores que, motivados por sus propios principios, devastan el cuerpo social y privado, y lo arrojan a un espacio de terror y sumisión.

Los cuerpos que aparecen y los cuerpos que aún permanecen ocultos debido a las estrategias de desaparición forzada también son lecciones para los sobrevivientes en dictadura: por un lado, la imagen del cuerpo expuesto opera como estrategia de disciplinamiento en la comunidad, ampliando el margen del castigo, y por otro, el ocultamiento y manipulación de los cuerpos de quienes fueron catalogados como "enemigos públicos" (García en Richard 91) provocan una gran herida en las familias que no pueden expresar su duelo con propiedad.

Patricio Guzmán relata en su documental la historia de los cuerpos que fueron escondidos en Calama durante el paso de la Caravana de la Muerte. Nos cuenta que después un tiempo fueron removidos con maquinaria pesada para ser embolsados y lanzados al mar. Victoria Saavedra, hermana de uno de los desaparecidos, sostiene en sus manos y describe los restos que tanto buscan las mujeres del desierto: "estos huesitos que son más planos, pienso, que deben ser astillas de fémur o hueso largo de brazo, porque normalmente están recubiertos y son bastante lisos. Pero estos deben ser de la parte interior de algún hueso por la forma, es poroso. Pero están todos blancos por la calcinación del desierto, del sol". La exposición de estos cuerpos igualmente es recogida en el testimonio del coro de la versión uruguaya: "Yo fui detenida a los 19 años con mi compañero, estaba embarazada. A él lo balearon y lo dejaron tirado en la calle. A mí me empezaron a torturar en mi casa y después me llevaron al cuartel". El carácter utilitario de los cuerpos oprimidos en dictadura queda a merced de un poder que se permite indiscreciones, esto quiere decir, modula los márgenes de visibilidad con el objetivo de infundir miedo y "demostrar que no hay recurso posible en contra de un poder que sustrae a las miradas de la mayoría de sus actos de violencia más extremos" (García en Richard 84). En ese sentido, las apariciones y desapariciones penetran en el campo imaginario y modifican las prácticas de la comunidad, rompiendo el vínculo social mediante prohibiciones.

Por su parte, el Siluetazo que acompaña las marchas de las Madres de Plaza de Mayo desplaza la ausencia física y la transforma en presencia simbólica. La postura política que exigía la aparición con vida de sus hijos y familiares produjo otro tipo de acercamiento al cuerpo faltante, pues ellas no buscaban rendirle honores fúnebres, sino incorporarlos nuevamente a la ciudad, poniendo en evidencia "eso que la opinión pública ignoraba o prefería ignorar, eso que se sabía y a la vez no se sabía" (Longoni y Bruzzone 31). En ese sentido, la silueta es una huella que representa dos cuerpos, el de quien presta su cuerpo para realizarla y el cuerpo del desaparecido, interpelando la dimensión política del duelo como cierre u olvido. Por otro lado, dejar una traza con el propio cuerpo homologaba la falta de quien desapareció con una falta posible cometida por cualquiera que se encontraba allí presente. Este giro en la comprensión del castigo señala que no existió una ley que hizo caer a algunos, sino una ley que cayó sobre la vida en general. 
La figura del desaparecido, provocada por los métodos criminales de las dictaduras, vino a trastocar la posibilidad misma de la experiencia del duelo por las políticas de eliminación radical, incluida la del cuerpo mismo de los sujetos asesinados. Es por esto que en la actualidad existen tumbas sin nombre y restos en cajas sin identificar -como dice Patricio Guzmán en su documental: "restos de restos" - que aún se encuentran suspendidos en el tiempo por la imposibilidad de restituirles su identidad y su historia. Estos cuerpos expuestos en democracia pierden su rol como dispositivo disciplinante debido a fórmulas y políticas de silenciamiento que los retiran de las discusiones públicas.

En la obra Antígona Oriental (2012), casi al final, se realiza un acto de reclamo al Estado y a la sociedad civil indiferente, gritándoles enfáticamente los nombres de quienes se beneficiaron con la impunidad y arrojándoles las fotografías de los desaparecidos. La doble desaparición, como castigo extendido, fue llevada a cabo por los gobiernos posteriores a la dictadura que se encargaron de controlar los excesos de verdad y dolor. Siguiendo esta idea, el Creonte mítico expresa "si a los mismos parientes mantengo yo sin freno ¿qué no harán los extraños?” (Sófocles 52), mientras que los Creontes orientales se dirigen a los habitantes uruguayos diciendo: "ciudadanos, ciudadanas, hemos restablecido con firmeza el orden en la ciudad, después de la violencia que hemos vivido". Ambas frases enuncian el castigo, devenido en control social, que impusieron los procesos de democratización. Un rasgo de esto queda en evidencia cuando el cuerpo del Hemón oriental aparece envuelto en la bandera uruguaya y es arrojado al escenario: la muerte instrumentalizada y ocultada mediante políticas de la memoria que buscan establecer un orden exento de desbordes.

\section{La desobediencia ante la ausencia del duelo}

Sabemos que tanto en la tragedia de Sófocles como en el conflicto inconcluso de las dictaduras hubo posiciones marcadamente en contra de las órdenes que impedían el encuentro entre el cuerpo y sus deudos. De acuerdo con esto, la desobediencia de Antígona resulta similar a la desobediencia llevada a cabo por las mujeres familiares de los detenidos desaparecidos que reclaman conocer la verdad sobre los últimos días de vida de sus familiares, reencontrarse con ellos y despedirse a través de los ritos correspondientes. Sin embargo, el gesto de la heroína mítica — toma de palabra para defender la familia - se diferencia de lo realizado por estas mujeres. Las Antígonas modernas transforman la concepción de hermano y lo extienden de manera que sea posible reivindicar los derechos de cualquier ser humano, es decir, ya no se trata de una voz privada e individual, sino una pública y colectiva. Esto queda reflejado en los dichos de Antígona mítica cuando justifica sus actos delante de Creonte: "marido, muerto el mío, podría tener otro y un hijo de otro hombre si perdiera yo el mío; pero ya que la madre y el padre allá en el Hades se encuentran, no es posible que me 
nazca otro hermano" (Sófocles 66), frente a la Antígona oriental, quien señala que "no hay otra forma de vivir si no es comprometida con los actos públicos, con los actos privados, con la intimidad, comprometida, sin mirar para el costado haciéndote la desentendida". Lo mismo sucede con las Madres cuando convocan a marchar y apoyar el Siluetazo, pues se trataba de un gesto político realizado públicamente en nombre de todas y todos.

El rechazo profundo a las leyes de Creonte fue motivo de una serie de sucesos que delinearon su figura de mujer rebelde. Pese a las recomendaciones de su hermana Ismena, decide no solo enterrar a Polinices, sino además enfrentar verbalmente a su tío para defender y justificar su acción. Siguiendo esta idea, la búsqueda de los familiares desaparecidos también está acompañada de actos desobedientes; es el caso de Violeta Berrios, entrevistada por Patricio Guzmán, quien nos cuenta sobre el sentido de sus actos: "han sido tantas veces que hemos ido con la Vicky a la pampa, tantas, tantas. Hemos ido con tanta esperanza y nos hemos venido con la cabeza en la tierra. Pero la hemos sacado, nos hemos sacudido y hemos partido nuevamente al otro día con las mismas o con más esperanza, más ganas, con más deseo de encontrarlos”. La necesidad de encontrar a sus hermanos articula su rechazo y exige hacer uso de su voz para reclamar sus derechos. En ese sentido, la experiencia dolorosa persistente en el presente requiere el replanteamiento del conflicto para conseguir instalar aquello que fue lo excluido del espacio público por considerarse peligroso.

Antígona sabe perfectamente que sus actos tienen un costo elevado, es ella quien lo asume sin temor delante del monarca. En la versión uruguaya, cuando Creonte le reclama por el entierro de Polinices, la heroína replica "no es ninguna vergüenza honrar a los hermanos". La frase enunciada, como mencionamos anteriormente, alude al carácter reivindicativo colectivo, trascendiendo el cuerpo de su hermano. La heroína continua su frase diciendo "soy una joven que quiere vivir, quiero decir cosas importantes a los gobernantes", declarando su postura contra la muerte mientras queden temas pendientes. La experiencia de Violeta Berrios es similar cuando exclama en el desierto "si yo los encontrara hoy día y me dicen mañana te mueres, yo me voy feliz. Pero no me quiero morir, no me quiero morir sin encontrarlo". En ambos textos podemos identificar el deseo por denunciar las injusticias cometidas en dictadura, antes de entregarse libremente a la muerte, como es el caso de la Antígona mítica.

Las mujeres de Calama buscaron durante 28 años a sus familiares, hasta el 2002, sin embargo hubo muchas otras mujeres buscadoras a lo largo de Chile y el continente. Las Madres de Plaza de Mayo se unieron a esta lucha pero de otra manera; ellas, al levantar la consiga de aparición con vida, gestionaron otra relación con los cuerpos de sus familiares desaparecidos. El Siluetazo como procedimiento para la apropiación colectiva se convirtió en un tipo de duelo colectivo "por su voluntad de oponer, como una impugnación, la presencia fantasmática de los desaparecidos a un régimen que empezaba a disolverse" (Expósito 2). Pero la verdadera restitución sucede cuando, luego de escuchar el proyecto de los artistas, las Madres deciden que las siluetas no 
pueden ir en el piso, debido a su connotación directa con la muerte, sino pegadas verticalmente en los muros "para afirmar la condición vital de las mismas" (Longoni y Bruzzone 224) y, así, rodear la marcha y empapelar los principales edificios del centro de Buenos Aires. En ese sentido, la restitución del cuerpo ausente como imagen-silueta constituye el duelo que transgrede la injusta ley que los hizo desaparecer. Estas acciones fueron repetidas en varias oportunidades durante el proceso de democratización, mientras que se establecían las listas para el informe "Nunca más" de la CONADEP.

La desobediencia civil de las Antígonas modernas pretende desafiar el estado de las cosas, en el pasado autoritario y en el presente posdictatorial, estableciendo acciones que cuestionan el orden establecido mediante su testimonio. Así queda manifestado en la parte final de Antígona Oriental (2012) cuando Ismena encara al público diciendo "ella habla por todas las que no podemos hablar porque el miedo nos anuló, porque la represión nos aniquiló, porque nacimos en una tierra contaminada por la impunidad”, respondiendo a los dichos de Creonte, quien gritaba “¡Se terminó! Ahora es tiempo de silencio. Y tu silencio es necesario para todos, por el bien de todos debes callar, Antígona”. Una estrategia de silenciamiento similar sucede en el caso de las mujeres del desierto; Violeta reflexiona sobre este punto y señala "yo creo que ellos son felices en la medida que van quedando menos mujeres, menos problemas. Porque nosotras somos un problema, para la sociedad, para la justicia, para todos somos un problema”. De acuerdo con esto, la fragilidad del testimonio ante el discurso dominante nos recuerda la disputa entre fuerzas que estructuran el mito, es decir, el "trayecto de la ruptura a la reposición" (Gatti 53) que no termina de concretarse en los hipertextos trabajados, salvo en Antígona Oriental, por la imposibilidad de resarcir los crímenes y silencios cometidos.

De acuerdo con esto, en la medida en que se siga protegiendo a los responsables del desaparecimiento de cientos de personas, manteniendo dudas sobre su paradero y conservando un cuerpo expuesto sin duelo, seguirán existiendo mujeres que los busquen incansablemente, resistiéndose a la prescripción del olvido, tal como lo menciona Violeta Berrios en el documental: "si a mí me dijeran, mira, los tiraron en la punta del cerro, yo no sé cómo pero voy a llegar a la punta del cerro. No tengo la fuerza de hace 20 años atrás, no tengo la salud de hace 20 años atrás, entonces va a ser un poco difícil, pero la esperanza da mucha fuerza”. Lo mismo sucede en la versión uruguaya del mito cuando Antígona imagina el futuro y exclama "nadie nunca más nos robará la historia. Cuando se conozcan los nombres de los rehenes también se sabrá que hubo heroínas que no tuvieron fotos, que no tuvieron prensa. Cuando las leyes vuelvan a escribirse". Tal vez, esa reescritura posibilite la comprensión de estos temas a través de un debate público que determine sanciones contra quienes manipularon los estatutos de la vida, indeterminando la muerte y fragmentando el cuerpo social mediante estrategias de desaparición y control. 


\section{Referencias}

Bachelard, G. El agua y los sueños: ensayo sobre la imaginación de la materia. Trad. Ida Vitale. México, D. F., Fondo de Cultura Económica, 2003.

Duroux, R. "Cuando dialogan dos Antígonas: La tumba de Antígona de María Zambrano y Antígona furiosa de Griselda Gambaro”. Olivar (online), vol. 13, n. ${ }^{\circ}$ 17, 2012, pp. 55-72. Disponible en http://www.scielo.org.ar/scielo.php?pid=S185244782012000100004\&script=sci_arttext (Revisado el 01/07/2015).

Eliade, M. Lo sagrado y lo profano, 1998. Disponible en: http://www.fcaglp.unlp.edu. ar/ sixto/arqueo/curso/Lo\%20Sagrado\%20y\%20lo\%20Profano.pdf (Revisado el 01/07/2015).

-_. Mito y realidad. Barcelona, Labor, 1991.

Expósito, M. “Representación de lo irrepresentable”. Revista La Vanguardia, Suplemento Cultura/s, pp. 2-5, 2009, Barcelona.

Gatti, R. "El Homo Sacer (des) enmascarado: El entrelazamiento de documento y símbolo para la repotenciación de la vida política en Antígona Oriental de Volker Lösch y Marianella Morena”. Tesis para optar al grado de Magíster en Literatura Hispanoamericana. Pontificia Universidad Católica del Perú, 2014.

Nostalgia de la luz. Dirigida por Patricio Guzmán, Chile, Francia y Alemania, Blinker Filmproduktion/WDR/ Cronomedia/Atacama Productions, 2010.

Lariguet, G. “Tragedia y política. Desde la Antígona de Sófocles a la Antígona Furiosa de Gambaro". Anacronismo e Irrupción, vol. 5, n. 8, pp. 297-315, 2015.

Longoni, A. y Bruzzone, G. El Siluetazo. Buenos Aires, Adriana Hidalgo Editora, 2008. Antígona Oriental. Dirigida por Volker Lösch y Marianella Morena. Uruguay, GoetheInstitut, 2012.

Marín, H. “Muerte, memoria y olvido”. Thémata. Revista de Filosofía, n. 37, pp. 309$319,2006$.

Richard, N. Políticas y estéticas de la memoria. Santiago de Chile, Cuarto Propio, 2000. Sófocles. Antígona. Santiago de Chile, Editorial Universitaria, 1983.

Vitullo, J. "Nostalgia de la luz de Patricio Guzmán: el cine como máquina del tiempo". Kamchatka n. ${ }^{\circ}$ 2, pp. 179-192, 2013.

Enviado: 19 de febrero de 2018 Aceptado: 10 de diciembre de 2018 